\title{
PENGAMBILAN KEPUTUSAN UNTUK MENIKAH BEDA ETNIS: STUDI FENOMENOLOGIS PADA PEREMPUAN JAWA
}

\author{
Yolanda Imelda Fransisca Tuapattinaya, Sri Hartati
}

\author{
Fakultas Psikologi Universitas Diponegoro \\ Jl. Prof. Sudharto SH, Tembalang, Semarang 50275 \\ fransiscayola.ft@gmail.com
}

\begin{abstract}
It is uneasy for Javanese women to make a decision to marry a non-Javanese man. Previous experiences with inter-ethnicities socialization play important roles to influence one's decision to undergo an inter-ethnicities marriage. Decision-making process is defined as a selection process of many available alternatives, including cognitive, motive, and attitude aspects. This study aims to describe the decision making process of the Javanese women to marry non-Javanese men. Three adult women (within age range 20-40 years old), who were Javanese, and married with a non-Javanese man (Bataknese or Papuan) participated in this study. Observation and depth interview were used to collect qualitative data. The findings show that having similarities in age and religious beliefs (or religion) were the main consideration for these Javanese women to marry their non-Javanese husband. Two Javanese women encountered parents' disagreement with their decisions to marry a non-Javanese man; parents encouraged them to marry a Javanese man. Another one woman could choose freely her non-Javanese man to marry with. The results also indicated that their decision making to marry followed these five steps: appraising the challenge, surveying alternatives, weighing of alternatives, deliberating about commitment, and surviving from negative feedback. Love and intimacy were two internal factors they considered before making decision to marry a non-Javanese man.
\end{abstract}

Keywords: inter-ethnicities marriage, decision making, Javanese women

\begin{abstract}
Abstrak
Bukanlah hal yang mudah bagi perempuan Jawa untuk memutuskan menikah beda etnis. Latar belakang pergaulan antar-etnis dapat berperan dalam membentuk pengalaman yang akhirnya dapat mempengaruhi keputusan seseorang untuk menikah beda etnis. Pengambilan keputusan didefinisikan sebagai proses memilih beberapa alternatif pilihan yang ada dimana melibatkan aspek seperti kognisi, motif, dan sikap. Penelitian ini bertujuan untuk mendeskripsikan pengambilan keputusan pada perempuan Jawa yang menikah beda etnis. Subjek penelitian ini adalah tiga orang perempuan dewasa (usia 20-40 tahun) etnis Jawa yang menikah dengan pria non-Jawa (etnis Batak dan Papua). Metode observasi dan wawancara mendalam (depth interview) digunakan untuk mengumpulkan data. Hasil penelitian menunjukkan bahwa persamaan usia dan keyakinan (agama) merupakan faktor yang dipertimbangkan subjek sebelum mengambil keputusan untuk menikah beda etnis. Dua dari tiga subjek menghadapi pertentangan dari orangtua mereka yang menginginkan subjek menikah dengan pria Jawa, sedangkan satu subjek lainnya memiliki kebebasan untuk memilih pasangan hidupnya. Hasil penelitian ini juga menunjukkan bahwa pengambilan keputusan untuk menikah dilakukan melalui beberapa tahap, yaitu penilaian informasi, survei alternatif, menimbang alternatif, dan menyatakan komitmen, serta bertahan dari umpan balik negatif. Cinta dan kebutuhan akan kehangatan merupakan faktor internal yang menjadi pertimbangan subjek dalam pengambilan keputusan.
\end{abstract}

Kata kunci: pernikahan beda etnis, pengambilan keputusan, perempuan Jawa

\section{PENDAHULUAN}

Menikah merupakan satu langkah penting dalam kehidupan seorang yang harus dipertimbangkan secara matang. Menikah tidak hanya melibatkan laki-laki dan perempuan, tetapi melibatkan juga keluarga dari pihak calon suami dan istri. Masyarakat Indonesia dikenal dengan sistem budaya patrilineal meskipun 
sebenarnya terdapat variasi corak patriarki antarbudaya. Salah satu masyarakat yang dikenal dengan kebudayaannya yang patriarkis adalah Jawa. Masyarakat Jawa merupakan masyarakat yang memiliki pembatasan-pembatasan tertentu dalam relasi gender yang memperlihatkan kedudukan dan peran laki-laki yang lebih dominan dibanding perempuan. Dalam budaya Jawa yang cenderung patrilineal, laki-laki memiliki kedudukan yang istimewa.

Wirawan (dalam Handayani, 2004) mengungkapkan bahwa wanita dalam budaya Jawa sering disebut sebagai kanca wingking (teman di dapur) oleh suaminya yang nasibnya sepenuhnya tergantung pada suaminya: "swarga nunut, neraka katut (ke surga ikut, ke neraka pun terbawa)”, bunyi salah satu pepatah Jawa. Secara kultural, budaya Jawa memandang bahwa tugas seorang perempuan adalah macak (berhias), masak, dan manak (melahirkan) dengan wilayah operasi dapur, sumur, dan kasur. Dalam pandangan hidup orang jawa, juga dikenal tiga kesetiaan seorang perempuan, yakni ketika kecil harus 'patuh' kepada orangtua, ketika dewasa harus 'patuh' kepada suami, dan ketika tua harus 'patuh' kepada anak-anaknya (Supatra, 2007). Berbagai pandangan mengenai wanita Jawa di atas seakan-akan menegaskan bahwa wanita Jawa kurang memiliki peran yang kuat dalam memutuskan apa yang menjadi keinginannya dan cita-citanya.

Pemilihan jodoh dan perkawinan sangat ketat dilakukan oleh orangtua dalam keluarga Jawa. Keadaan ini menunjukkan seakan-akan hak pengambilan keputusan tidak ada dalam diri seorang wanita Jawa. Adanya sikap "narimo" terhadap keputusan keluarga adalah hal yang utama dalam keluarga Jawa. Perkataan dan perintah orangtua dianggap sebagai suatu keharusan untuk diikuti oleh anak-anak.
Pernikahan beda etnis merupakan fenomena yang banyak terjadi. Etnis yang satu dengan etnis yang lain memiliki sistem kebudayaan yang berbeda. Perbedaan kebudayaan yang paling menonjol dan dapat disoroti adalah sistem nilai budaya. Nilai budaya berfungsi sebagai konsep yang berlaku pada suatu masyarakat dimana nilai tersebut lahir. Individu yang tumbuh dalam masyarakat yang memiliki nilai budaya, sejak kecil meresapi nilai tersebut. Dalam mencapai keputusan menikah beda etnis, perbedaaan nilai budaya menjadi pertimbangan bagi individu yang bersangkutan. Bertemunya dua etnis dengan nilai budaya yang berbeda akan membutuhkan adaptasi dan adaptasi tersebut mengandung konsekuensi. Konsekuensi yang timbul berupa konflik, baik konflik internal -yang berasal dalam diri individu- maupun konflik eksternal -yang berasal dari lingkungan luar. Hal tersebut memengaruhi proses pengambilan keputusan.

Menurut Suryadi dan Ramdhani (1998) pengambilan keputusan pada dasarnya merupakan bentuk pemilihan dari berbagai alternatif tindakan yang mungkin dipilihnya yang prosesnya melalui mekanisme tertentu, dengan harapan akan menghasilkan sebuah keputusan yang terbaik. Adapun faktor-faktor yang berperan dalam pengambilan keputusan adalah kognisi, motif, dan sikap. Kognisi berkaitan dengan perihal berpikir, mempertimbangkan, dan mengamati. Motif berkaitan dengan dorongan, keinginan, dan hasrat. Kecenderungan untuk bereaksi terhadap sesuatu berkaitan dengan sikap.

Dari deskripsi yang dipaparkan di atas, peneliti ingin mengamati dan meneliti wanita Jawa dengan semua tanggapan yang berlaku dalam masyarakat Jawa tentang pengambilan keputusan untuk menikah beda etnis. Penelitian tentang pengambilan keputusan seorang wanita Jawa menikah beda etnis ini penting karena dalam 
masyarakat Jawa, memilih pasangan hidup atau jodoh sangat memperhatikan bibit, bebet, bobot. Prasangka etnis juga masih menjadi topik pembicaraan, terlebih bila berkaitan dengan pengambilan keputusan untuk menikah beda etnis. Perbedaan nilai budaya dari pasangan yang merancang pernikahan beda etnis juga dapat menimbulkan konflik, sehingga terjadilah proses pengambilan keputusan.

Menurut Janis \& Mann (1979) pengambilan keputusan adalah suatu proses pemilihan terhadap alternatif yang dianggap terbaik oleh individu. Proses tersebut meliputi tahapan-tahapan yang harus dilalui individu, dimana pada setiap tahapan tersebut individu dihadapkan pada alternatif yang harus dipilihnya dalam mencapai tujuan yang diharapkan. Proses pemilihan itu tidak selalu mudah untuk dilakukan. Beberapa keputusan besar bisa menyebabkan individu mengalami konflik dalam mengambil keputusan.

Adapun tahapan pengambilan keputusan adalah sebagai berikut (Janis \& Mann, 1979):

Tahap 1: Menilai informasi atau masalah (appraising the challenge). Ketika individu menerima informasiyang tidak jelas atau informasi yang menurutnya jauh dari harapan, maka ia akan mempertahankan sikap mengenai tindakan yang ia ingin lakukan. Penerimaan informasi yang tidak jelas ini menyebabkan individu mengalami konflik sementara (personal temporary crisis) dan mulai ragu dengan apa yang telah dipercayai selama ini. Individu akan mulai mencari alternatif jika pertanyaan kunci memberikan respons positif setelah keputusan pertama. Ditegaskan oleh Janis dan Mann (1979), ketika individu menghadapi sebuah tantangan dan berakhir dengan sukses pada tahap pertama maka kondisi tersebut dapat memberikan sesuatu yang baru. Pembuat keputusan akan lebih siap untuk menghadapi temuan yang baru untuk melakukan tindakan sesuai dengan yang diinginkan.

Tahap 2: Mensurvei alternatif (surveying alternatives). Setelah kepercayaan seseorang terhadap kebijakan atau pemikiran lamannya diguncang oleh informasi baru, dimana ia merasa ada konsekuensi negatif jika ia tidak mengambil tindakan, dia mulai memfokuskan perhatian pada satu atau lebih pilihan-pilihan lain. Dia mulai mencari berbagai alternatif tindakan dan meminta saran atau informasi dari orang lain untuk menghadapi masalahnya, walaupun melanggar atau tidak sesuai dengan komitmennya. Sebagian besar keputusan mengarah pada komitmen awal, namun dengan adanya stimulus kuat yang diterimanya, ia mulai mencari informasi baru mengenai alternatif lain yang lebih baik.

Tahap 3: Menimbang alternatif (weighting of alternatives). Individu pada tahap ini menuju pada analisis dan evaluasi yang lebih dalam dengan berfokus pada sisi positif dan negatif pada tiap alternatif yang tersedia sampai ia merasa yakin untuk memilih satu alternatif yang sesuai dengan tujuannya. Secara umum, tahap ini ditandai oleh keragu-raguan dimana individu tidak lagi merasa puas dengan tindakan atau tindakan terdahulu namun juga belum berkomitmen pada alternatif baru. Ketika ia mencapai titik yakin bahwa ia tahu dimana pilihan terbaik, dia biasanya akan tetap terus responsif terhadap informasi baru.

Tahap 4: Menyatakan komitmen (deliberating about commitment). Setelah secara internal memutuskan akan mengambil tindakan baru, individu mulai membicarakan dengan hati-hati mengenai penerapan keputusan tersebut dan menyatakan niatnya pada orang lain.

Tahap 5: Bertahan dari feedback negatif. Banyak individu yang merasa senang dan 
nyaman dengan keputusan baru yang diambil tanpa keragu-raguan. Namun seringkali keadaan tersebut terganggu oleh munculnya feedback negatif dari pihak lain. Individu akan bertahan pada tahap ini sampai ia berhadapan dengan peristiwa atau hal yang sangat kuat untuk menimbulkan ketidakpuasan terhadap pilihan yang telah diambil. Jika hal tersebut terjadi, ia akan melalui tiga tahapan diatas, kemudian mencari alternatif-alternatif lain yang berbeda dan lebih baik.

Menurut Rakhmat (2007) masih belum banyak yang dapat diungkap tentang proses penetapan keputusan. Meski demikian ada kesepakatan bahwa faktor-faktor personal sangat menentukan apa yang diputuskan itu, antara lain kognisi, motif, dan sikap. Pada kenyataanya, kognisi, motif, dan sikap ini berlangsung sekaligus.

Kognisi artinya kualitas dan kuantitas pengetahuan yang dimiliki (Rahmat, 2007). Menurut Chaplin (2004) kognisi didefinisikan sebagai suatu konsep umum yang mencakup semua bentuk pengenalan. Termasuk di dalamnya ialah mengamati, melihat, mempehatikan, memberikan, menyangka, membayangkan, memperkirakan, berpikir, mempertimbangkan, menduga, dan menilai.

Walgito (2004) mendefinisikan motif sebagai kekuatan yang terdapat di dalam diri organisme yang mendorong untuk berbuat atau merupakan driving force. Motif, menurut Sarwono (2000), erat hubungannya dengan gerak; dalam hal ini gerakan yang dilakukan oleh manusia atau disebut juga perbuatan atau tingkah laku. Motif dalam psikologi berarti rangsangan, dorongan, pembangkit tenaga bagi terjadinya suatu tingkah laku. Gerungan (2004) menyatakan motif melingkupi semua penggerak, alasan atau dorongan dalam diri manusia yang menyebabkan ia berbuat sesuatu. Semua tingkah laku manusia pada hakikatnya mempunyai motif. Motif pada manusia dapat bekerja secara sadar maupun tidak sadar. Mengerti dan memahami tingkah laku manusia secara sempurna, maka terlebih dahulu memahami apa dan bagaimana motif-motif dari tingkah lakunya.

Sikap didefinisikan sebagai suatu predisposisi atau kecenderungan yang relatif stabil dan berlangsung terus-menerus untuk bertingkah laku atau untuk mereaksi dengan satu cara tertentu terhadap pribadi lain, objek, lembaga, atau persoalan tertentu. Menurut Sarwono (2002), sikap dapat didefinisikan sebagai kesiapan pada seseorang untuk bertindak secara tertentu terhadap suatu hal tertentu.

Ensiklopedia Indonesia menyatakan, perkawinan adalah nikah; sedangkan menurut Purwadamita (dikutip Walgito, 2002) kawin adalah perjodohan laki-laki dan perempuan menjadi suami istri. Disamping itu, menurut Hornby (dikutip Walgito, 2002), pernikahan adalah bersatunya dua orang sebagai suami istri. Menurut Undang-Undang Pernikahan, yang dikenal dengan Undang-Undang No.1 Tahun 1974, yang dimaksud dengan pernikahan adalah ikatan lahir batin antara seorang pria dan seorang wanita sebagai suami istri dengan tujuan membentuk keluarga (rumah tangga) yang bahagia dan kekal berdasarkan Ketuhanan Yang Maha Esa.

Turner \& Helms (dalam Dariyo, 2003) mengklasifikasikan motivasi pernikahan menjadi lima motif, yaitu:

a. Motif cinta

Cinta dan komitmen sering kali dijadikan dasar utama bagi pasangan laki-laki dan perempuan untuk melangsungkan pernikahan. Untuk mempertahankan komitmen cinta, tidak ada cara lain dengan melanggengkannya dalam pernikahan. 
b. Motif kecocokan

Cinta dapat tumbuh karena adanya kecocokan atau kesamaan di antara kedua pasangan hidup. Banyak pasangan yang melangsungkan pernikahan karena mereka memiliki kecocokan atau kesamaan minat. Misalnya, memiliki hobi, pekerjaan/karier, dan asal daerah atau agama yang sama. Dengan kesamaan tersebut, diperkirakan mereka akan mudah menyesuaikan diri dalam kehidupan berkeluarga.

c. Motif untuk memperoleh legitimasi (pengakuan sah secara hukum) terhadap pemenuhan kebutuhan biologis.

Diraih-nya status pernikahan yang sah, baik dari segi agama maupun administrasi peme-rintahan negara (undang-undang atau hukum perkawinan), individu mem-peroleh pengesahan untuk melakukan hubungan seksual dengan pasangan hidupnya. Mereka tidak dianggap me-langgar peraturan, norma-norma sosial atau hukum yang sah bila melakukan hal tersebut. Justru hukum sosial telah melindungi dari perbuatan asusila.

d. Motif untuk memperoleh legitimasi status anak

Anak-anak yang lahir dari hubungan yang terikat dengan lembaga pernikahan, akan memperoleh pengakuan yang sah dihadapan ajaran agama atau hukum Negara. Mereka berhak mendapatkan pemeliharaan dan tanggung jawab yang layak dari oarngtuanya sampai mereka dewasa dan mandiri.

e. Merasa siap secara mental untuk menikah Kesiapan mental untuk menikah mengandung makna sebagai kondisi psikologis-emosional untuk siap menanggung berbagai resiko yang timbul selama hidup dalam pernikahan, misalnya pembiayaan ekonomi keluarga, mendidik dan memelihara anak-anak, dan membiayai kesehatan keluarga. Kesiapan mental seseorang, erat kaitannya dengan unsur usia, pendidikan, dan status karier atau pekerjaan.

\section{METODE}

Subjek penelitian ini adalah tiga orang perempuan dewasa (usia 20-40 tahun) etnis Jawa yang menikah dengan pria non-Jawa (etnis Batak dan Papua). Penelitian ini menggunakan metode kualitatif dengan pendekatan fenomenologi. Wawancara mendalam dan observasi digunakan untuk mengumpulkan data kualitatif.

\section{HASIL DAN PEMBAHASAN}

Erikson (dalam Santrock, 1995) menyatakan bahwa masa dewasa awal individu menghadapi tugas perkembangan pembentukan relasi intim dengan orang lain. Maka, menyadari tugas perkembangannya, individu mulai membangun dan menjalin relasi dengan orang lain. Hubungan interpersonal dibentuk dari perkenalan yang disebut acquaintance process (Rakhmat, 2007). MY, NDR, dan PN mengalami tahap perkenalan yang mengawali pembentukan hubungan interpersonal. Tahap perkenalan ini menghasilkan komunikasi interpersonal.

Komunikasi interpersonal yang langsung (bertatap muka) adalah bentuk komunikasi yang paling lengkap dan mengandung berbagai faktor psikologis (Sarwono, 2002). Dalam masa pacaran, komunikasi MY dengan pacarnya didominasi oleh Short Message Services (SMS), sedangkan PN berusaha untuk aktif berkomunikasi dengan pacarnya karena sebelumnya pacarnya yang melakukan adaptasi alloplastis terhadap PN dalam komunikasi. Dalam hubungan dengan pacarnya, NDR yang memiliki rasa benci terus menumbuhkan perasaan tersebut karena kurangnya komunikasi dengan pacarnya. Namun, setelah komunikasi 
terjalin dengan lancar, NDR mulai membuka diri terhadap pacarnya, sehingga ada perubahan perilaku.

Semakin besar komunikasi yang terjalin antar individu, maka semakin besar kecenderungan untuk tertarik satu sama lain (Rakhmat, 2007). Kesukaan pada orang lain, sikap positif dan daya tarik seseorang disebut sebagai ketertarikan interpersonal. Faktor-faktor yang memengaruhi ketertarikan interpersonal (Rakhmat, 2007) adalah daya tarik fisik, ganjaran (reward), familiarity, kedekatan (proximity) dan kemampuan (competency).

MY dan PN memperlihatkan ketertarikan mereka terhadap pacar masing-masing. MY dan PN memilki ketertarikan interpersonal, yaitu tertarik akan kepribadian pacar mereka. Selain ketertarikan interpersonal, MY memiliki ketertarikan emosional. Berbeda dengan MY dan PN, NDR sama sekali tidak menunjukkan ketertarikannya terhadap pacarnya karena ia merasa benci pada kondisi fisik pacarnya. Namun, ketertarikan tersebut ada ketika pacarnya melakukan komunikasi dan adaptasi alloplastis terhadap NDR dan budayanya.

Dalam hubungan pacaran yang mempertemukan dua individu, secara otomatis akan ada penyesuaian diri di dalamnya. Penyesuaian diri autoplastis ditunjukkan oleh MY dan PN. MY memperlihatkan penyesuaian dirinya terhadap cara bicara pacarnya yang sering bernada tinggi yang jarang ia jumpai ketika berbicara dengan orang Jawa. Sedangkan $\mathrm{PN}$, beradaptasi dengan mengontrol dirinya ketika sang pacar mengekspresikan emosi marahnya. Penyesuaian komunikasi juga dilakukan NDR, yaitu beradaptasi terhadap dialek etnis Papua atau cara bicara pacarnya yang yang cepat, sehingga dapat memahami topik yang dibicarakan.

Dalam hubungan interpersonal lintas-etnis, akan terjadi penilaian lintas-etnis. Penilaian bisa bermakna positif maupun negatif. Penilaian lintas-etnis terjadi dan didahului oleh persepsi lintas-etnis. Penilaian lintasetnis yang diperlihatkan ketiga subjek adalah penilaian dalam bentuk positif. MY memandang etnis Batak adalah etnis yang terbuka dan ekspresif dalam menyampaikan sesuatu. Berbeda dengan MY, NDR menilai orang Papua setia dan jujur, serta memiliki integritas yang tinggi. Sementara bagi PN, tidak semua etnis Batak bersifat keras. Penilaian positif tersebut menyebabkan subjek terbuka dan menerima perbedaan etnis dengan pacarnya, seperti yang ada pada MY dan NDR.

Perasaan cinta menjadi pertimbangan semua subjek sebelum memutuskan menikah beda etnis. Cinta mengacu pada perilaku manusia yang sangat luas dan kompleks (Santrock, 1995). Teori cinta triangular (the triangular theory of love) adalah teori Sternberg yang menyatakan bahwa cinta memiliki komponen: gairah, keintiman dan komitmen (Santrock, 1995). Gairah digambarkan dalam daya tarik fisik dan seksual. Keintiman adalah perasaan emosional tentang kehangatan, kedekatan, dan berbagi dalam hubungan. Komitmen merupakan penilaian kognitif atas hubungan dan niat untuk mempertahankan hubungan bahkan ketika menghadapi masalah. NDR memperlihatkan bahwa ia memiliki kebutuhan akan keintiman yang akan ia peroleh dalam pernikahan bersama pacarnya.

Kepribadian pacar juga dipertimbangkan MY, NDR, dan PN sebagai usaha memantapkan diri sebelum sampai pada keputusan menikah beda etnis. Kepribadian mengacu pada penilaian trait. Trait terbagi dua, yaitu common trait dan individual trait. Common trait terdapat hampir sama pada masing-masing individu, sedangkan individual trait adalah sifat khusus yang dimiliki oleh seseorang dan belum tentu dimiliki oleh orang lain. Penilaian yang 
dilakukan ketiga subjek menggambarkan penjabaran atas individual trait dari masing-masing pasangan.

Keluarga memiliki peran yang sangat besar dalam proses pengambilan keputusan menikah beda etnis. MY, NDR dan PN mendapat dukungan orangtua terhadap keputusan mereka. Keputusan MY untuk menikah adalah untuk menyenangkan orangtuanya dan ia mendapat dukungan penuh. PN pun juga merasakan dukungan orangtua dan penerimaan orangtua terhadap keputusan yang diambilnya untuk menikah beda etnis. Bagi NDR, walaupun ia mendapat dukungan dari keluarga, khususnya orangtua, ia harus melewati proses yang cukup panjang sebelum mendapatkan persetujuan untuk menikah beda etnis. Pada mulanya, orangtua NDR tidak menyetujui NDR untuk menikah dengan pacarnya yang beretnis Papua. Di satu sisi, NDR ingin membahagiakan orangtuanya jika ia menikah dengan etnis Jawa, namun di sisi lain ia juga mencintai pacarnya. Maka timbullah konflik.

Keluarga NDR menentang hubungan NDR dengan pacarnya akibat prasangka etnis. Menurut Baron dan Byrne (dalam Sarwono, 2002) prasangka didefinisikan sebagai sikap yang negatif terhadap kelompok tertentu atau seseorang, semata-mata karena keanggotaannya dalam kelompok tertentu. Dampak negatif yang ditimbulkan dari prasangka adalah adanya stereotip (sifatsifat khas yang seakan-akan melekat pada suatu kelompok). Orangtua NDR meyakini bahwa orang Papua sering bertindak kasar dan mereka mencemaskan kemungkinan hal serupa menimpa NDR. Dalam mengkomunikasikan hubungan dengan pacarnya, NDR bersikap asertif terhadap orangtuanya yang tidak menyetujui hubungan itu.

Keputusan menikah beda etnis dipilih oleh MY, NDR, dan PN sebagai hasil akhir dari proses pengambilan keputusan. Menurut
Janis \& Mann (1979) pengambilan keputusan memiliki tahapan yaitu menilai informasi, mensuvei alternatif, menimbang alternatif, hingga akhirnya menyatakan komitmen sebagai keputusan akhir dari proses tersebut. MY, NDR, dan PN memiliki pola yang sama yaitu melewati tahapan pengambilan keputusan dan dipengaruhi oleh faktor internal dan faktor eksternal dalam pengambilan keputusan. Dengan demikian, pengambilan keputusan bukan sesuatu yang mudah, melainkan melewati proses.

\section{KESIMPULAN}

Ketiga subjek memiliki latar belakang pergaulan lintas etnis sehingga pengalaman pergaulan tersebut membuat mereka melakukan penilaian yang bersifat positif.

Faktor internal dan eksternal turut berperan dalam proses pengambilan keputusan menikah beda etnis. Faktor internal mencakup kognisi, motif, sikap, hambatan internal, penyesuaian diri, dan harapan akan masa depan.

Dukungan sosial merupakan faktor eksternal yang berperan penting, meliputi: dukungan orangtua, keterbukaan orangtua, dan penerimaan orangtua. Ketiadaan dukungan dari orangtua dapat berbentuk penolakan terhadap pasangan (menantu).

Modal utama yang memantapkan ketiga subjek untuk memutuskan menikah beda etnis adalah kesamaan kepercayaan (agama) dengan pasangan serta usia atau kematangan untuk menikah. Pengalaman pergaulan beda etnis juga mempengaruhi subjek dalam mempertimbangkan pernikahan beda etnis. Pergaulan multietnis dapat melahirkan penilaian positif terhadap perbedaan etnis dengan pasangan dan menimbulkan pergeseran nilai budaya dalam pemilihan pasangan hidup. 


\section{DAFTAR PUSTAKA}

Bungin, B. (2007). Penelitian Kualitatif: Komunikasi, Ekonomi, Kebijakan Publik, dan Ilmu Sosial Lainnya. Jakarta: Kencana.

Chaplin, J. P. (2004). Kamus Lengkap Psikologi. Penerjemah: Kartini Kartono. Jakarta: PT. Raja Grafindo Persada.

Dariyo, A. (2003). Psikologi Perkembangan Dewasa Muda. Jakarta: Grasindo.

Gerungan, W. A. (2004). Psikologi Sosial. Bandung: PT Eresco.

Handayani, C. S. \& Novianto, A. (2004). Kuasa Wanita Jawa. Yogyakarta: Penerbit LKIS.

Janis, I. L. \& Mann, L. (1979). Decision Making: A Psychological Analysis of Conflict, Choice and Commitment. New York: The Free Press.

Poerwandari, E. K. (2007). Pendekatan Kualitatif untuk Penelitian Perilaku Manusia. Depok: LPSP3.

Rakhmat, J. (2007). Psikologi Komunikasi. Bandung: Remaja Rosdakarya.
Sarwono, S. W. (2000). Pengantar Psikologi Umum. Jakarta: Bulan Bintang.

Santrock, J. W. (1995). Psychology. New York: McGraw-Hill Higher Education.

Sarwono, S. W. (2002). Psikologi sosial: Individu dan teori-teori psikologi sosial. Jakarta. Balai Pustaka

Supatra, H., Astuti, S. P., \& Suharyo. (2007). Stereotip Perempuan Dalam Bahasa Indonesia Dalam Rumah Tangga Di Pantai Utara Jawa Tengah [online]. Diambil dari http://lemlit.undip.ac.id/ abstrak/content/view/246/288/

Suryadi, K. \& Ramdhani, A. (1998). Sistem Pendukung Keputusan. Bandung: Remaja Rosdakarya.

Walgito, B. (2002). Bimbingan dan Konseling Perkawinan. Yogyakarta: Andi.

Walgito, B. (2004). Pengantar Psikologi Umum. Yogyakarta: Andi. 